\title{
Effect of animal species on muscle colour characteristics
}

Violeta Razmaité ${ }^{1}$,

Virginija Jatkauskienė,

Aušra Bajorinaitè,

Rūta Šveistienė,

Artūras Šiukščius

Animal Science Institute of

Lithuanian University of Health Sciences,

R. Žebenkos St. 12,

LT-82317 Baisogala,

Radviliškis District, Lithuania
The objective of the study was to determine and compare the colour characteristics as a distinctive biological feature of animals from different domestic and wild animal species. Colour measurements were made on the fresh cuts of $m$. longissimus of pigs, beef cattle, red deer, rabbit, brown hare, on the $m$. pectoralis profundus of horse, on the $m$. pectoralis major of goose and on the hind leg muscles of red deer, rabbit, brown hare and goose within 5 min of blooming. CIE colour expressions, such as lightness $\left(\mathrm{L}^{*}\right)$, redness $\left(\mathrm{a}^{*}\right)$, yellowness $\left(\mathrm{b}^{*}\right)$, chroma $(\mathrm{C})$ and hue angle $(\mathrm{h})$ were measured using a chromameter CR-410. Differences in colour parameters of different muscles within species were negligible, but species highly affected all studied parameters. Rabbit and pig showed the highest meat lightness. Brown hare and red deer showed the highest redness and colour saturation followed by beef and horse, but the highest meat yellowness was in rabbit and horse followed by pig. Negative Pearson's correlation coefficients between the meat $\mathrm{pH}$ and colour parameters were found in pork and beef, however, no significant correlations were estimated between these traits in meat of red deer, horse and rabbit.

Key words: colour, meat, species

\section{INTRODUCTION}

Different species are significantly different on sensory attributes that give adequate descriptions of species (Rødbotten et al., 2004). Meat colour is related with different forms of the sarcoplasmatic protein myoglobin, and it depends on different factors and genetics (Mancini, 2009). Colour also provides information about attributes describing simililarities or dissimilarities between animal species and represents perceived freshness of meat. Meat purchasing decisions are influenced more by product

\footnotetext{
* Corresponding author. E-mail: Violeta.Razmaite@lsmuni.lt
}

appearance than any other quality factor (Mancini, Hunt, 2005; Ngapo et al., 2007; Wu, Sun, 2013; Gracia, de Magistris, 2013). Consumers use colour as an intrinsic cue to predict experienced sensory quality (Banović et al., 2012) Although nowadays there are genetic methods for meat identification (Bargen et al., 2014; Fajardo et al., 2014; Santos et al., 2012), colour is one of the most important attributes that determine animal species identification and consumer acceptance of meat. The perception of colour is a very complex phenomenon that depends on the composition of the object in its illumination environment, the characteristics of the perceiving eye and brain, and the angles of 
illumination and viewing ( $\mathrm{Wu}$, Sun, 2013). Therefore the employment of instrumental methods for colour measurement and control was quite necessary (León et al., 2006; Wu, Sun, 2013). Currently, many options are available for instrumental colour analysis. The effects of different factors and methods of determining meat colour within different species were recorded (Gil et al., 2008; Liu et al., 2009; Boukha et al., 2011; Luciano et al., 2012). However, there are large variations in the instrument used and in the use of illuminant and colour coordinates (Tapp et al., 2011). Therefore, the objective of this study was to determine and compare the colour characteristics and their relationships with muscle $\mathrm{pH}$ as a distinctive biological feature of animals from different domestic and wild animal species measured using the same instrument and methods.

\section{MATERIALS AND METHODS}

Meat samples were excised from the chilled carcasses after 24 hours post mortem. Colour measurements were made on the fresh cuts of $m$. longissimus of pigs, beef cattle, red deer, rabbit, brown hare, on the $m$. pectoralis profundus of horse, on the $m$. pectoralis major of goose and on the hind leg muscles of red deer, rabbit, brown hare and goose within $5 \mathrm{~min}$ of blooming. CIE colour expressions, such as lightness $\left(L^{*}\right)$, redness $\left(a^{*}\right)$, yellowness $\left(b^{*}\right)$, chroma $(\mathrm{C})$ and hue angle $(\mathrm{h})$ were measured in the $\mathrm{L}^{*} \mathrm{a}^{*} \mathrm{~b}^{\star}$ and $\mathrm{L}^{*} \mathrm{C}^{\star} \mathrm{h}$ colour space using a chromameter CR-410 Konica Minolta (Japan) equipped with a $50 \mathrm{~mm}$ aperture using a C illuminant and $2^{\circ}$ standard observer. The chromameter was calibrated to a white standard $(Y=85.3, x=0.3173, y=0.3251)$ plate before measurements.

The statistical analysis data were analyzed using the general linear model procedure of the SPSS Statistics 17.0 software. The LSD test was used to compare differences among the mean values of meats from different animal species. The mean values and the standard error of the means (SE) were reported. Bivariate Pearson's correlations between $\mathrm{pH}$ and col- our parameters were calculated. The significance was defined at $P<0.05$.

\section{RESULTS AND DISCUSSION}

Differences in colour parameters of different muscles within species were negligible, but species highly affected all studied parameters (Table 1). Since pork is consumed most in Lithuania and globally (Font-i-Furnols, 2014), pig was used as a model animal for comparison of meat colour from different species. Only muscles of rabbit had higher $(\mathrm{P}<0.001)$ meat lightness $\left(\mathrm{L}^{*}\right.$ values $)$ compared with the pig longissimus dorsi (LD) muscle (Table 1). Since $\mathrm{L}^{*}$ is the lightness component, which ranges from 0 to 100 (from black to white), the darkest colour was in the muscles of brown hare, in the $m$. pectoralis profundus of horse and in the muscles of red deer. The highest redness $\mathrm{a}^{*}$ was shown by the thigh and LD muscles of brown hare and red deer followed by beef and horse, however, the significant higher redness of brown hare muscles $(\mathrm{P}<0.001)$ was the only compared with those of pig, rabbit and goose. The lowest $\mathrm{a}^{*}$ values $(\mathrm{P}<0.001)$ were in rabbit and pig. Instrumental measures of $\mathrm{L}^{\star}$ and $\mathrm{a}^{*}$ are straightforward and can easily be applied to the muscle colour (Mancini, Hunt, 2005). The colours represented by $b^{*}$ (from blue to yellow) are not typical or intuitively related to meat, therefore assessment of meat yellowness $\left(b^{*}\right)$ is difficult for panellists, however, it is successfully presented by instrumental measurements. In the present study the highest meat yellowness was in rabbit and horse followed by pig. The lowest and significantly different compared with pig $\mathrm{b}^{*}$ values were detected in the meat of goose $\mathrm{P}<0.001)$ and beef $(\mathrm{P}<0.05)$. Colour saturation (chroma or $\mathrm{C}$ ) which is defined as the colourfulness of an area judged in proportion to its brightness was highest in brown hare and red deer followed by beef cattle. The lowest chroma was estimated in rabbit and pig followed by goose. Chroma of pork significantly differed from chroma of beef, horse, red deer and hare meat $(\mathrm{P}<0.001)$. The hue angle $(\mathrm{h})$ is defined as the attribute of a visual sensation according to which an area appears to be similar to one of 


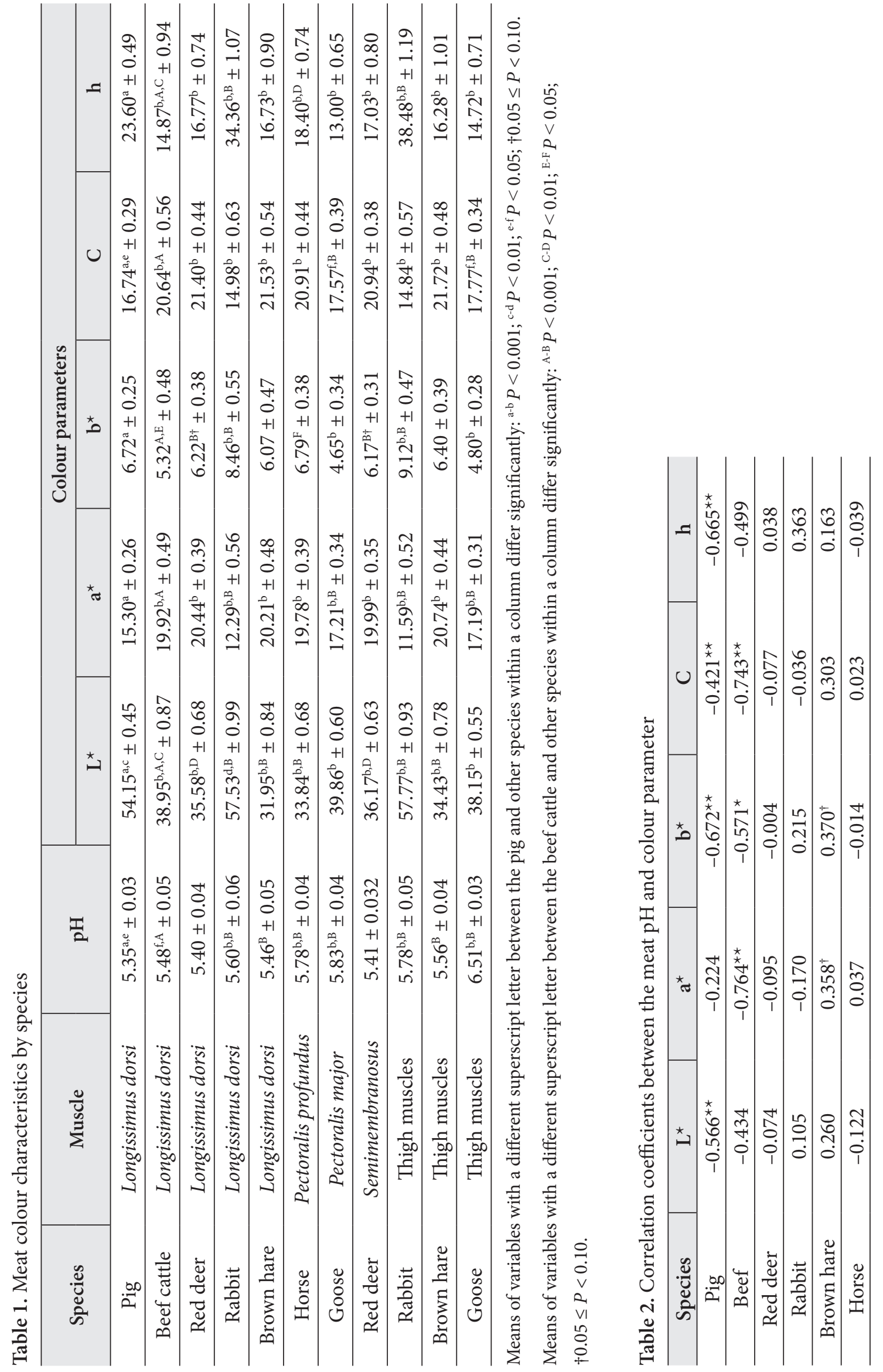


the perceived colours: red, yellow, green, and blue, or to a combination of two of them (Fairchild, 2005). Hue presented a similar trend to $\mathrm{L}^{*}$, being lower in values. Mancini and Hunt (2005) have reviewed that the inseparable relationship between the product colour and $\mathrm{pH}$ is widely accepted. In the present study Pearson's correlation coefficients between the $\mathrm{pH}$ and colour parameters (Table 2 ) showed negative correlations with $\mathrm{L}^{*}, \mathrm{~b}^{*}, \mathrm{C}$ and $\mathrm{h}$ in pigs $(\mathrm{P}<0.01)$, whereas in beef $\mathrm{pH}$ negatively correlated with $\mathrm{a}^{*}(P<0.01), \mathrm{b}^{*}(P<0.05), \mathrm{C}(P<0.01)$ and tended to correlate with hue $(0.05 \leq P<0.10)$, and these are in agreement with other authors who have found these traits highly discriminant in pork and beef (Mancini, Hunt, 2005). Similar correlations in pork have been reported by Gil et al. (2008). However, Boukha et al. (2011) have reported that phenotypic correlations were low, but $\mathrm{pH}$ and $\mathrm{L}^{\star}$ and $\mathrm{b}^{\star}$ values were genetically associated in beef. No differences in lamb meat lightness and other colour parameters were observed between the meat with different ultimate $\mathrm{pH}$ by Luciano et al. (2012). In the present study no significant correlations were estimated between $\mathrm{pH}$ and colour parameters in the meat of red deer, horse and rabbit. The negative correlation between $\mathrm{pH}$ and $\mathrm{L}^{*}(P<0.05)$ was found in the meat of goose. The tendency $(0.05 \leq P<0.10)$ of an opposite positive relationship between $\mathrm{pH}$ and $\mathrm{a}^{\star}$ and $\mathrm{b}^{\star}$ was estimated in brown hare.

\section{CONCLUSIONS}

Differences in colour parameters of different muscles within species were negligible, but species highly affected all studied parameters and relationships between $\mathrm{pH}$ and colour. Rabbit and pig showed the highest meat lightness. The highest redness and colour saturation was shown by brown hare and red deer followed by beef and horse, but the highest meat yellowness was in rabbit and horse followed by pig. Negative Pearson's correlation coefficients between the meat $\mathrm{pH}$ and colour parameters were found in pork and beef, however, no significant correlations were estimated between these traits in the meat of red deer, horse and rabbit.

\section{ACKNOWLEDGEMENTS}

This research work was funded by a grant No. SVE-07/2012 from the Research Council of Lithuania.

Received 2 June 2015

Accepted 2 August 2015

\section{References}

1. Banović M, Aguiar Fontes M, Barreira MM, Grunert KG. Impact of product familiarity on beef quality perception. Agribusiness. 2012; 28: $157-72$.

2. Bargen C, Brockmeyer J, Humpf HU. Meat authentication: a new HPLC-MS/MS based method for the fast and sensitive detection of horse and pork in highly processed food. J Agric Food Chem. 2014; 62: 9428-35.

3. Boukha A, Bonfatti V, Cecchinato A, Albera A, Gallo L, Carnier P, Bittante G. Genetic parameters of carcass and meat quality traits of double muscled Piemontese cattle. Meat Sci. 2011; 89: 84-90.

4. Gil M, Delday MI, Gispert M, Font i Furnols M, Maltin CM, Plastow GS, et al. Relationships between biochemical characteristics and meat quality of longissimus dorsi and semimembranosus muscles in five porine lines. Meat Sci. 2008; 80: 927-33.

5. Gracia A, de Magistris T. Preferences for lamb meat: A choice experiment for Spanish consumers. Meat Sci. 2013; 95: 396-402.

6. Fajardo V, González I, Rojas M, García T, Martin R. A review of current PCR-based methodologies for the authentication of meats from game animal species. Trends Food Sci Tech. 2014; 21: 408-21.

7. Fairchild MD. Color appearance models. 2nd ed. England: John Wiley \& Sons Ltd.; 2005.

8. Font-i-Furnols M, Guerrero L. Consumer preference, behavior and perception about meat and meat products: An overview. Meat Sci. 2014; 98: 361-71. 
9. León K, Mery D., Pedreschi F, León J. Color measurement in $\mathrm{L}^{*} \mathrm{a}^{*} \mathrm{~b}^{*}$ units from RGB digital images. Food Res Int. 2006; 39: 1084-91.

10. Luciano G, Biondi L, Pagano IR, Scerra M, Vasta V, López-Andrés $P$, et al. The restriction of grazing duration does not compromise lamb meat colour and oxidative stability. Meat Sci. 2012; 92: 30-5.

11. Liu HW, Gai F, Gasco L, Brugiapaglia A, Lussiana C, Guo KJ, Tong JM, Zoccarato I. Effects of chesnut tannins on carcass characteristics, meat quality, lipid oxidation and fatty acid composition of rabbits. Meat Sci. 2009; 83: 678-83.

12. Mancini RA, Hunt MC. Current research in meat color. Meat Sci. 2005; 71: 100-21.

13. Mancini RA. Meat color. In: Kerry JR, Ledward D, editors. Improving the sensory and nutritional quality of fresh meat. CRC Press: Woodhead Publishing Limited; 2009. p. 89110.

14. Ngapo TM, Martin J-F, Dransfield E. International preferences for pork appearance: I. Consumer choices. Food Qual Prefer. 2007; 18: 26-36.

15. Rødbotten M, Kubberød M, Lea P, Ueland $\varnothing$. A sensory map of the meat universe. Sensory profile of meat from 15 species. Meat Sci. 2004; 68: $137-44$.

16. Santos CG, Melo VS, Amaral J, Estevinho L, Beatriz M, Oliveira PP, Mafra I. Identification of hare meat by a species-specific marker of mitochondrial origin. 2012; 90: 836-41.

17. Tapp III WN, Yancey JWS, Apple JK. How is the instrumental color of meat measured? Meat Sci. 2011; 89: 1-5.

18. Wu D, Sun DW. Colour measurements by computer vision for food quality control. A review. Trends Food Sci Tech. 2013; 29: 5e20.
Violeta Razmaitė, Virginija Jatkauskienè, Aušra Bajorinaitė, Rūta Šveistienè, Artūras Šiukščius

\section{GYVŪNŲ RŪŠIES ĮTAKA RAUMENŲ SPALVOS RODIKLIAMS}

\section{Santrauka}

Tyrimo tikslas - įvertinti ir palyginti skirtingų ūkinių ir laukinių gyvūnų rūšių raumenų spalvos rodiklius. Matuota kiaulių, mėsinių galvijų, tauriụjų elnių, triušių, pilkujjų kiškių ilgiausiojo nugaros raumens, arklių giliojo krūtinès ir žąsų didžiojo krūtinès raumens šviežio pjūvio per 5 minutes spalva. Ivvertinta ir elnių, triušių, kiškių, žąsų šlaunų raumenų spalva. Chromametru CR-410, turinčiu $50 \mathrm{~mm}$ apertūrinę angą, taikant $\mathrm{C}$ apšvietimą ir $2^{\circ}$ standartinę apžvalgą, nustatytos CIE sistemos spalvos šviesumo $L^{*}$, rausvumo $a^{*}$, gelsvumo $b^{*}$, spalvos sodrumo $C$ ir atspalvio kampo $h$ reikšmès. Skirtingų tos pačios gyvūnų rūšies raumenų spalvos rodiklių skirtumai buvo nedideli, bet skirtingu gyvūnų rūšių mėsos spalvos rodikliai labai skyrèsi. Šviesiausia buvo triušių ir kiaulių mèsa, itin rausva ir sodria spalva išsiskyrè kiškių, elnių, galvijų ir arklių, o didesniu gelsvumu pasižymėjo triušių, arklių ir kiaulių mėsa. Tarp kiaulienos ir jautienos $\mathrm{pH}$ ir spalvos rodikliu nustatyta neigiama Pearsono koreliacija, tačiau koreliacijos tarp šių rodiklių elnienoje, arklienoje ir triušienoje nenustatyta.

Raktažodžiai: spalva, mėsa, rūšis 